\title{
THE INFLUENCE OF BRAND ATTITUDE ON BEHAVIORAL INTENTION IN THE CONTEXT OF NATIONAL CARRIER'S SERVICE FAILURE
}

\author{
Owais B. AL-GHARAIBEH \\ Taibah University, College of Business Administration, 42353 Medina, Saudi Arabia, e-mail: ograibah@taibah.edu.sa \\ Ahmad Azmi M. ARIFFIN* \\ Universiti Kebangsaan Malaysia, UKM-Graduate School of Business, 43600 UKM Bangi, Malaysia, e-mail: aama@ukm.edu.my
}

\begin{abstract}
Citation: Al-Gharaibeh, O.B., \& Ariffin, A.A.M. (2021). THE INFLUENCE OF BRAND ATTITUDE ON BEHAVIORAL INTENTION IN THE CONTEXT OF NATIONAL CARRIER'S SERVICE FAILURE. GeoJournal of Tourism and Geosites, 34(1), 193-196. https://doi.org/10.30892/gtg.34125-636
\end{abstract}

\begin{abstract}
Studies on the service failures involving a national carrier are still very limited. This present study strives to investigate the relationship between brand attitudes and behavioral intentions in the context of national carrier's service failures as well as the moderating effect of causal attribution on the above main relationship. Data were collected from 419 airline passengers using the purposive sampling technique. Path analysis was used to analyze the data. The effect of brand attitude on behavioral intention is found to be positive significantly. The results also showed that out of the two dimensions of causal attribution, only stability moderates the relationship between brand attitudes on behavioral intention.
\end{abstract}

Key words: brand attitude, behavioral intention, causal attributions, stability, controllability

\section{INTRODUCTION}

Service failure essentially occurs when service performance fails to meet customer expectation. It normally resulted in many negative consequences, such as negative word of mouth, customer complaints, as well as unfavourable attitude and behavioural intention toward the services as a whole (Ithnan and Ariffin, 2020; Ariffin and Mansour, 2018). Previous studies have also clearly indicated that service failures are the main reason for the customer switching behavior, and unfavorable brand recommendation (Latif and Lanxia, 2019; Akinci and Aksoy, 2019). Extant of literature showed that service failure has the potential to change a customer's attitude towards a brand from a positive one to a negative one and this will then affect the behavioral intention unfavorably (Habibi and Ariffin, 2019). Unquestionably, brand attitude is a widely researched construct in marketing studies but very little is currently known about its impacts on repurchase intention as well as word-of-mouth recommendation in the context of airline service failure involving national carriers. Al-Fandi (2020) contended that the two main indicators of behavioral intention are repurchase intention as well as intention to recommend.

The Causal Attribution theory suggested that customers will interpret the causes of a service failure based on the two most dominant dimensions known as stability and controllability (Weiner, 1986). The judgements of the perceived reasons for the failure will influence the decision as to whether or not to continue purchasing the same brand in the future, as well as the intention to recommend the brand to others. Therefore, it is posited in this present study that the impact of brand attitude on behavioral intention (operationalized as repurchase intention and word-of-mouth marketing) in the context of national carriers' service failure should also largely dependent on the attributions of the failure made by the affected passengers. If the cause of the failure is perceived to be within the control of the national carrier or preventable by the airlines, passengers will put the blame on the airlines and this will negatively affect their behavioral intention tow ards the national carrier as a whole (Nikbin et al., 2011). To what extent is the above claim true when the customers have relatively strong attachment with the brand such as in the context of national carriers involving the passengers from the country-of-origin of the airline?

National carrier is an airline registered in a given sovereign state and enjoys privileges and preferential rights by the local authority particularly for its international routes. According to Raguraman (1997), national carrier has played a very important role in nation building and acts as a significant national identity for many countries. Considering the fact that national carrier has been regarded as an important national symbol and prides for a given sovereign country, it is not wrong to assume that the citizens of the country would extend undivided and continuous supports for the survival of the airlines. It is therefore very interesting to uncover the post-failure reactions towards national carriers amongst its respected citizens. Does the attitude towards their national airlines (brand attitude) affect their behavioral intention, and to what extend the causal attributions moderate the above main relationship? Specifically, the research objectives of this study are:

1. To determine the relationship between brand attitude and behavioral intentions in the context of national carrier's service failure.

2. To examine the moderation effects of causal attribution dimensions (stability and controllability) on the relationship between brand attitude and behavioral intentions in the context of national carrier's service failure.

\section{CONCEPTUAL MODEL}

By using the Causal Attributions Theory, the conceptual framework of this study is developed and presented in Figure 1. The framework strives to determine the post-service failure's behavioral intention towards national carriers amongst the passengers of the airline's country-of-origin. In this present study, the behavioral intention is anticipated to be significantly affected by the brand attitude towards the brand (national carrier) and the strength of the predicted relationship between brand attitude and behavioral intention is expected to be moderated by the two core dimensions of causal attribution's known as controllability and stability. The intention is believed to be able to direct individuals to carry out a behaviour. A very recent study by Komariah et al. (2020) also clearly indicated that customer intention is very much dependent on the attitude towards the focal offering.

\section{LITERATURE REVIEW AND HYPOTHESES}

Essentially, brand attitude is defined as the continuous preference of consumers towards a specific brand (Fishbein and Ajzen, 1980)

\footnotetext{
* Corresponding author
} 
and the overall assessment made by the consumer vis-à-vis the brand (Ariffin and Yahaya, 2013). A favorable attitude towards a brand would increase the probability of consumers to continue using that brand in the future (Kotler and Keller, 2008). Peter and Olson (2002) contended that attitude towards an object (including brand) consists of salient beliefs acquired via experience, which can fluctuate between positive/negative as a function of past experiences with the object. Behavioral intention is the motivational factors affecting a behavior.

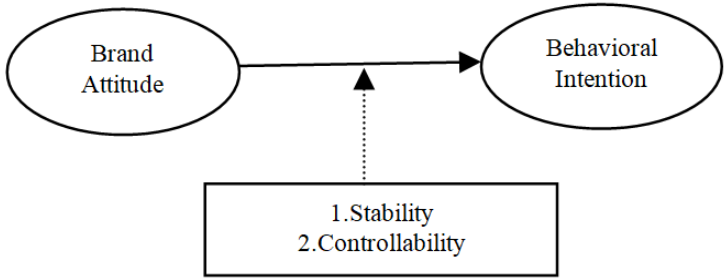

Figure 1. Conceptual Framework (Source: Author)

The stronger the intention to execute a behavior, the more likely it is to take place (Ajzen, 1991). Zeithaml et al., (1996) pointed out that behavioral intentions can be outlined by measures such as word-of-mouth, loyalty, complaining behavior, repurchase intentions and price sensitivity. Yasvari et al. (2012) utilized word-of-mouth as an indicator for referral intention, while Chou (2015) defined behavioral intention using attitude loyalty (recommendation of services) and behavior loyalty (repurchase intention). Similarly, Beneke and Wickham (2015) employed negative word-of-mouth as the outcome of service failure in the airline industry in South Africa.

The study on airlines' service failure by Nikbin et al. (2011) also used

both repurchase intention and word-of-mouth as the outcomes of behavioral intention in the marketing perspective. Alfandi (2020) operationalized the construct by using both revisit intention as well the willingness to recommend the destination. The research stream on service failure has reached its maturity (Khamitov et al., 2020). Attitude has been linked to many behavioral outcomes such as brand loyalty (Gomez et al., 2006; Schiffman and Kanuk, 2007). It was found to play a significant role towards forming brand loyalty (Gomez et al., 2006). Yasvari et al. (2012) examined the direct effect of attitude on referral intention and found a significant relationship between the variables. Punyatoya (2015) examined the effect of brand attitude on brand purchase intention of the environmental product, and confirmed that positive attitude towards the product leads to higher behavioral intention to purchase environmental products. Beneke and Wickham (2015) also reported that failure cause negative attitudes, which in turn leads to negative word-of-mouth. In a related study, Saha and Theingi (2009) pointed out that behavioral intention is subjective, and could thus be positive/negative. A negative attitude leads to negative word-of-mouth, or negative behavioral intention and anticonsumption, while a positive attitude leads to a positive behavioral intention. It was confirmed from literature that studies pertaining to the effect of attitude in the airline context are limited. Thus, it is anticipated in this study that:

\section{H1: There is a relationship between brand attitude and behavioral intention in the context of national carrier's service failure.}

The stability dimension of attributions essentially refers to the perception of the situations that led to the service failure as either persistent or infrequent (Srivastava and Gosain, 2020). The Causal Attribution theory developed by Weiner (1986) basically conceptualized the reaction of consumers to occurrences such as service failure (Maxham and Netemeyer 2002). The theory argued that when individuals make causal attribution, they are expected to be inclined towards a particular behavior based on their own explanations of the attributions. This phenomenon can be explained via two main dimensions namely controllability, and stability. Stability is referring to the extent a cause of failure is considered as temporary or permanent (Folkes, 1984). Failures based on stable causes will take place more frequently compared to the unstable one. Nikbin et al. (2011) studied the moderating effect of stability on the relationship between company reputation and behavioral intention, and confirmed that the permanent cause of service failure degraded the relationship between reputation and repurchase intention, as well as positive word-of-mouth. What about in the context of national carrier's service failure? This present study anticipates that:

\section{H2: Stability moderates the relationship between brand attitude and behavioral intention in the context of national carrier's service failure.}

Controllability refers to the ability of a company or entity to control service failure or the accident (Folkes, 1984). Customers will relate service failure to the ability of the company to prevent/cause failures (Weiner, 2000). If customers think that the cause of failure is uncontrollable, they will not blame the service providers, but if they believe failure is controllable and internal, they will tend to be dissatisfied and blame the service providers (Nikbin et al., 2011). Therefore, when a problem is controllable, the positive relationship between brand attitude and behavioral intention is weaker. In contrast, when customers feel that the cause of the failure is uncontrollable, they put less blame on the service providers. Papen et al. (2020) also indicated that controllability has a significant moderating effect on the relationship between disappointment with the organization and intention to repurchase. Accordingly, the following hypothesis is proposed for testing in this present study:

H3: Controllability moderates the relationship between brand attitude and behavioral intention in the context of national carrier's service failure.

\section{RESEARCH METHOD}

By using the judgmental sampling, a total of 480 self-administered questionnaires were distributed at the Kuala Lumpur International Airport (KLIA), Malaysia in April 2020. Respondents were confined only to individual airline passengers who have experienced flying using the national carriers of their own countries within the last six months from the time of data collection. Out of the 460 , only 419 were found to be usable for further analysis. 41 questionnaires were discarded mainly due to missing responses. The measurement for brand attitude consists of five items adapted from Grace and O'Cass (2005). The eight items used to measure the causal attribution of stability and controllability were adapted from Hess et al. (2003) and Russell (1982) while behavioral intention was measured using four items borrowed from Zeithaml et al. (1996). All items for all variables were measured on a 6-point scale. A panel of three experts has been appointed to refine and validate the measurements for all variables in this study. Pre-testing and pilot-test have also been carried out prior to data collection for the actual study. Path analysis was employed to analyze the data of this present study. A preliminary analysis has also been conducted to ensure that there is no issue on the data violation as well as all assumptions have been satisfactorily fulfilled. Below are the main stages involved in the methodology of this present study:

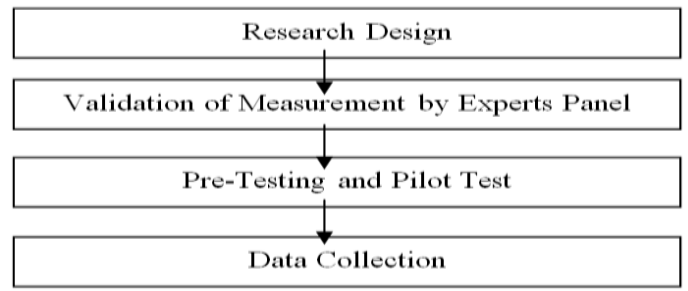

Table 1. Reliability test

\begin{tabular}{|l|c|c|}
\hline \multicolumn{1}{|c|}{ Variable } & Number of items & Cronbach's alphas \\
\hline Brand attitude & 5 & 0.90 \\
\hline Stability & 4 & 0.79 \\
\hline Controllability & 4 & 0.82 \\
\hline Behavior intention & 4 & 0.89 \\
\hline
\end{tabular}

Figure 2. Stages in Research Methodology (Data Source: Author) 


\section{RESEARCH FINDINGS}

Throughout the six days field work, a total of 463 questionnaires have been returned. However, due to extensive missing values and outlier issues, only 419 were found to be appropriate for further analysis.

Reliability and Validity

As presented in Table 1, the results showed that the values of Cronbach's alphas for all variables ranged from 0.79 to 0.90 . These values exceeded the cut-off point of 0.70 as suggested by Nunnally and Bernstein (1994) to assess the internal consistency of the measurements.

For a model to have a convergent validity, three criteria must be achieved. First the factor loading should be greater than 0.70 , composite reliability (CR) as well as Cronbach's Alpha (CA) should be greater than 0.70, and Average Variance Extracted (AVE) should be greater than 0.50 (Hair et al., 2011). Table 2 shows the factor loadings, CA, CR, and AVE. It shows that all the values of the criteria were achieved. This leads to the conclusion that the convergent validity and construct reliability are achieved. The results presented in Table 3 also showed that the discriminant validity was also achieved as the root square of AVE (in bold) are greater than its row and column.

Table 2. Convergent Validity of the Variables

\begin{tabular}{|c|c|c|c|c|c|}
\hline Variables & Items & Factor loading $<0.70$ & $\mathrm{CA}<0.70$ & $\mathrm{CR}<0.70$ & $\mathrm{AVE}<0.50$ \\
\hline \multirow{5}{*}{ Brand Attitude } & AT1 & 0.76 & \multirow{5}{*}{0.90} & \multirow{5}{*}{0.93} & \multirow{5}{*}{0.71} \\
\hline & AT2 & 0.88 & & & \\
\hline & AT3 & 0.86 & & & \\
\hline & AT4 & 0.85 & & & \\
\hline & AT5 & 0.86 & & & \\
\hline \multirow{4}{*}{$\begin{array}{l}\text { Behavioral } \\
\text { Intention }\end{array}$} & BI1 & 0.85 & \multirow{4}{*}{0.89} & \multirow{4}{*}{0.93} & \multirow{4}{*}{0.76} \\
\hline & BI2 & 0.90 & & & \\
\hline & $\mathrm{BI} 3$ & 0.88 & & & \\
\hline & BI4 & 0.85 & & & \\
\hline \multirow{3}{*}{ Controllability } & $\mathrm{CO} 1$ & 0.70 & \multirow{3}{*}{0.82} & \multirow{3}{*}{0.88} & \multirow{3}{*}{0.71} \\
\hline & $\mathrm{CO} 2$ & 0.88 & & & \\
\hline & $\mathrm{CO} 3$ & 0.93 & & & \\
\hline \multirow{3}{*}{ Stability } & ST1 & 0.85 & \multirow{3}{*}{0.79} & \multirow{3}{*}{0.86} & \multirow{3}{*}{0.68} \\
\hline & ST3 & 0.75 & & & \\
\hline & ST4 & 0.87 & & & \\
\hline
\end{tabular}

Path Analysis

The result of the path analysis as presented in Table 4 showed that brand attitude has a significant and positive effect on behavioral intention $(\beta=0.41$, T-value=9.63, P-value=0.00). With R Square of $0.47, \mathrm{H} 1$ was supported.

The results presented in Table 5 indicated that the effect of the interaction of stability and brand attitude (Stability* Atti tude -> Intention) and behavioral intention was positive and significant $(\beta=-0.13, \mathrm{~T}=2.39, \mathrm{P}=0.02)$. This finding provided empirical support for H2 - Stability moderates the relationship between brand attitude and behavioral intention. The results presented in Table 6 indicated that the effect of the interaction of controllability attribution and brand attitude (Controllability*Attitude $->$ Intention) and behavioral intention was not significant $(\beta=0.057, \mathrm{~T}=1.54, \mathrm{P}=0.12)$. This finding provided no empirical support for $\mathrm{H} 3$ in this pre sent study. It can be concluded that controllability attribution does not moderates the relationship between brand attitude and behavioral inten tion.

Table 5. Moderating Effect of Stability

\begin{tabular}{|l|c|c|c|c|c|c|}
\hline & $\begin{array}{c}\text { Orig. } \\
\text { Sample }\end{array}$ & $\begin{array}{c}\text { Sample } \\
\text { Mean }\end{array}$ & S.D & $\mathrm{T}$ & $\begin{array}{c}\mathrm{P} \\
\text { Values }\end{array}$ & Decision \\
\hline $\begin{array}{l}\text { B.Attitude -> B. } \\
\text { Intention }\end{array}$ & 0.44 & 0.44 & 0.04 & 10.22 & 0.00 & \\
\hline $\begin{array}{l}\text { Stability -> } \\
\text { B.Intention }\end{array}$ & 0.11 & 0.11 & 0.05 & 2.05 & 0.04 & \\
\hline $\begin{array}{l}\text { Stability*B.Attitude } \\
\text {-> Intention }\end{array}$ & -0.13 & 0.13 & 0.05 & 2.39 & 0.02 & Supported \\
\hline
\end{tabular}

Table 6. Moderating Effect of Controllability

\begin{tabular}{|l|c|c|c|c|c|c|}
\hline & $\begin{array}{c}\text { Orig. } \\
\text { Sample }\end{array}$ & $\begin{array}{c}\text { Sample } \\
\text { Mean }\end{array}$ & S.D & T & $\begin{array}{c}\text { P } \\
\text { Values }\end{array}$ & Decision \\
\hline $\begin{array}{l}\text { B.Attitude -> B. } \\
\text { Intention }\end{array}$ & 0.38 & 0.04 & 0.04 & 9.27 & 0.00 & \\
\hline $\begin{array}{l}\text { Controllability-> } \\
\text { B.Intention }\end{array}$ & 0.21 & 0.04 & 0.05 & 5.92 & 0.00 & \\
\hline $\begin{array}{l}\text { Controllability*B. } \\
\text { Attitude -> Intention }\end{array}$ & -0.06 & 0.04 & 0.05 & 1.54 & 0.12 & $\begin{array}{c}\text { Not } \\
\text { Supported }\end{array}$ \\
\hline
\end{tabular}

\section{DISCUSSIONS AND IMPLICATIONS}

This present study provides empirical evidence on the positive impact of brand attitude on behavioral intention in the context of national carrier's service failure. It is clearly showed that brand attitude is a powerful explanatory variable or determinant of beha vioral intention in both contexts of pre- and post-service failures. The more favorable the attitude towards the airlines, the more likely they will fly again with the airline in the future, recommend the airline to others or talk positively about the airline. Even though the affected airline is the national carrier of the passengers, the airlines management however should not simply take this sentiment of ethnocentrism for granted. It is crucial for the management to consistently build their brand image and reputation because the negative brand image will affect behavioral intention unfavorably. An effective service recovery strategy needs to be in place to ensure that the brand attitude towards the airline would not be largely affected. National carriers should also go extra miles to enlighten their domestic passengers with superb customer services in order to encourage them to promote and support the airline in all market situations. Unlike other commercial services, the psychological attachment to a national carrier among the people of its country-of-origin is essentially developed within the cultural context rather than the consumption setting. Perhaps, the change or shift in cultural phenomenon is required to make a change to the psychological bonding. The strength of the brand attitude towards a cultural artifact such as national carriers could not be easily changed. The state of brand attitude will lead to positive emotions or attachment with the brands. These strong attachment and favorable emotions will, in turn prevent the affected passengers from switching to any other airlines. The findings of this study also revealed that stability attributions weakened the positive relationships between brand attitude and behavioral intention in the context of national carrier's post-service failure. Passengers are said to be somewhat forgiving of a service failure caused by their own airlines compared to other airlines. However, if similar kind of service failure keep hapening over times, these passengers would start reconsidering their loyalty towards the national carriers involved. In other words, the interaction between brand attitude and stability attribution would lead to a less favourable behavioral intention towards the national carriers involved. Even though their brand attitude is remains unchanged due to other reasons, perhaps they would not want to recommend the airline to others. This is to avoid other people experiencing the inconveniences as the probability of the same failure to recur is relatively high.

This study however did not find the moderating effect of perceived controllability on the relationship between brand attitude and behavioral intention. In other words, regardless whether the cause of the failure is perceived to be within or beyond the con trol of the 
national carriers, the strength of the brand attitude's impact on behavioral intention will remain unchanged. Due to the tech nicality of the airline service provision, it is quite difficult for the affected passengers to determine what are the factors considered to be within and what factors are considered to be beyond the control of the airlines. The behavioral intention and loyalty of passengers toward national carriers will not be largely affected by only a single unpleasant service experience regardless of the source of the failure. Passengers are likely to be more considerate as the airline service is very unpredictable. This study may be considered as a guide for national carrier management to facilitate in-depth understanding of customer experiences and develop effective marketing strategies that will improve the operational environment and the experience of customers of national carrier. This is because, although the present study is primarily theoretical, it is believed that the conceptual relationship proposed may provide a useful and robust framework that can offer national carrier management valuable information on the factors that influence the behaviour of their potential passengers.

Specifically, in respect to brand attitude, this study offers national carriers a view of how consumers rate their relationship with service providers from the standpoint of brand attitude towards a national carrier after service failure. The results of this present study can assist national carrier management to improve their understanding of how brand attitude affects passenger behavioral intentions. The prescriptions proposed based on the findings can also help national carrier management to design and promote more effective and efficient strategies for ensuring positive brand attitude, which can lead to a significant increase in passenger retention and, ultimately, profits.

\section{CONCLUSION}

This present study which was focusing on the service failure of national carriers managed to achieve all its objectives succe ssfully. The results clearly indicated that brand attitude has a strong relationship with behavioral intention to fly again with those national carriers that have involved in service failures. The extent of the influence of brand attitude on behavioral intention was also found to be dependent on the stability attribution made by the affected passengers. Specifically, the stability attribution is expected to weakened the main relationship as passengers believe that the airlines are not doing their very best to avoid the failures from reoccurring over times. Interestingly, this present study did not find empirical support for the moderating effect of controllability attribution. This is mainly due to the fact that passengers are usually unable to examine what factors are considered to be controllable (uncontrollable) by the airlines.

\section{REFERENCES}

Aizen, I (1991). The Theory of planned behavior. Organizational Behavior and Human Decision Processes, 50, 179-211. https://doi.org/10.1016/0749-5978(91)90020-T

Akinci, S., \& Aksoy, S. (2019). The impact of service recovery evaluation on word-of-mouth intention: A moderated mediation model of overall satisfaction, household income and gender. Tourism Management Perspectives, 31, 184-194. https://doi.org/10.1016/j.tmp.2019.05.002

Alfandi, A.M. (2020). Is Jordan safe to visit? The impact of perceived risk perceptions on the tourist behavioral intentions. GeoJournal of Tourism and Geosites, 33(4spl), 1545-1550. https://doi.org/10.30892/gtg.334spl15-606

Ariffin, A.A.M., \& Mansour, J.S. (2018). The Influences of Authenticity and Experience Quality on Behavioural Intention in Cultural Heritage Destination. WSEAS Transactions on Business and Economics, 15, 394-403.

Ariffin, A.A.M., \& Yahaya, M.F. (2013). The relationship between airport image, national identity and passengers delight: A case study of the Malaysian low cost carrier terminal (LCCT). Journal of Air Transport Management, 31, 33-36. http://doi.org/10.1016/j.jairtraman.2013.02.005

Beneke, J., \& Wickham, B. (2015). The impact of willingness to engage in negative electronic word-of- mouth on brand attitude: A study of airline passengers in South Africa. Journal of Business and Retail Management Research, 9(2), 68-85. https://doi.org/10.24052/JBRMR/194

Chou, P.F. (2015). An analysis of the relationship between service failure, service recovery and loyalty for Low Cost Carrier travelers. Journal of Air Transport Management, 47, 119-125. http://doi.org/10.1016/j.jairtraman.2015.05.007

Fishbein, M., \& Ajzen, I. (1980). Understanding attitudes and predicting social behavior. Englewood Cliffs, NJ: Prentice-Hall;.

Folkes, V.S. (1984). Consumer reaction to product failure: An attributional approach. Journal of Consumer Research, 10, 398-409. https://doi.org/10.1086/208978

Gomez, B.G., Arranz, A.G., \& Cillán, J.G. (2006). The role of loyalty programs in behavioral and affective loyal ty. Journal of Consumer Marketing, 23(7), 387-396. https://doi.org/10.1108/07363760610712920

Habibi, A., \& Ariffin, A.A.M. (2019). Value as a medical tourism driver interacted by experience quality. Anatolia, 30(1), 35-46. https://doi.org/10.1080/ 13032917.2018 .1496122

Hair, J.F.Jr., Ringle, C.M., \& Sarstedt, M. (2011). PLS-SEM: Indeed a silver bullet. Journal of Marketing Theory and Practice, 19(2), 139-151. https://doi.org/10.2753/MTP1069-6679190202

Ithnan, I.H.M., \& Ariffin, A.A.M. (2020). Behavioral Intention Towards "Halal Hotels": Religiosity or Ethnicity. WSEAS Transactions on Business and Economics, 17, 58-73.

Hess Jr.R.L., Ganesan, S., \& Klein, N.M. (2003). Service failure and recovery: the impact of relationship factors on customer satisfaction. Journal of the Academy of Marketing Science, 31(2), 127. https://doi.org/10.1177\%2F0092070302250898

Khamitov, M., Grégoire, Y., \& Suri, A. (2020). A systematic review of brand transgression, service failure recovery and product-harm crisis: integration and guiding insights. Journal of the Academy of Marketing Science, 1-24. https://doi.org/10.1007/s11747-019-00679-1

Komariah, K., Razzaq, A.R.B.A., Nugraheni, M., Lastariwati, B., \& Mahfud, F. (2020). The antecedent factor of tourists' intention to consume traditional food. GeoJournal of Tourism and Geosites, 32(4), 1209-1215. https://doi.org/10.30892/gtg.32403-559

Kotler, P., \& Keller, K.L. (2008), Marketing management, 13th ed., Prentice-Hall, Upper Saddle River, NJ.

Latif, M.S., \& Lanxia, Z. (2019). The Impact of Service Recovery on Repurchase Intentions: A Moderated Mediation Model. Journal of Research in Administrative Sciences, 8(1), 10-25. https://doi.org/10.47609/JRAS2019v8i1p3

Maxham, J.G., \& Netemeyer, R.G. (2002). A Longitudinal Study of Complaining Customers' Evaluations of Multiple Service Failures and Recovery Efforts. Journal of Marketing, 66(4), 57-71. http://doi.org/10.1509/jmkg.66.4.57.18512

Nikbin, D., Ismail, I., Marimuthu, M., \& Abu-Jarad, I.Y. (2011). The impact of firm reputation on customers' responses to service failure: the role of failure attributions. Business Strategy Series, 12(1), 19-29. http://doi.org/10.1108/17515631111106849

Nunnally, J.C., \& Bernstein, I.H. (1994). Psychometric theory (3rd ed.). New York, NY: McGraw-Hill, Inc.

Papen, M.C., Siems, F.U., \& Kunz, W.H. (2020). The Influence of Childhood Engagement in the Context of Hospitality Service Failure Evaluation. Journal of Hospitality \& Tourism Research, 44(2), 403-425. https://doi.org/10.1177\%2F1096348019896086

Peter, J.P., \& Olson, J.C. (2002). Consumer behaviour and marketing strategy. (6th ed.), New York: McGraw-Hill Irwin.

Punyatoya, P. (2015). Effect of perceived brand environment-friendliness on Indian consumer attitude and purchase intention. Marketing Intelligence \& Planning, 33(3), 258-275. http://doi.org/10.1108/MIP-04-2013-0069

Raguraman, K. (1997). Airlines as instruments for nation building and national identity: case study of Malaysia and Singapore. Journal of transport geography, 5(4), 239-256. https://doi.org/10.1016/S0966-6923(97)00021-5

Russell, D. (1982), The causal dimension scale: a measure of how individuals perceive causes. Journal of Personality and Social Psychology, 42( 2), 1137-45. https://psycnet.apa.org/doi/10.1037/0022-3514.42.6.1137

Saha, G.C., \& Theingi (2009). Service quality, satisfaction and behavioral intentions: a study of low cost airlines in Thailand. Managing Service Quality , 19(3). https://doi.org/10.1108/09604520910955348

Schiffman, L., \& Kaunk L. (2007). Consumer attitude formation and change Consumer Behavior. Ninth Ed New York, Prentice hall, 238-259.

Weiner, B. (1986). An Attributional Theory of Motivation and Emotion. New York, Springer-Verlag.

Yasvari, T.H., Ghassemi, R.A., \& Rahrovy, E. (2012). Influential Factors on Word of Mouth in Service Industries (The case of Iran Airline Company) International Journal of Learning and Development, 2(5), 217-222. https://doi.org/10.5296/ijld.v2i5.2366

Srivastava, M., \& Gosain, A. (2020). Impact of Service Failure Attributions on Dissatisfaction: Revisiting Attribution Theory. Journal of Management Research, (09725814), 20(2).

Zeithaml, V.A., Berry, L., \& Parasuraman, A. (1996). The behavioral consequences of service quality. Journal of Marketing, 60, 31-46. https://doi.org/ $10.1177 \% 2$ F002224299606000203 